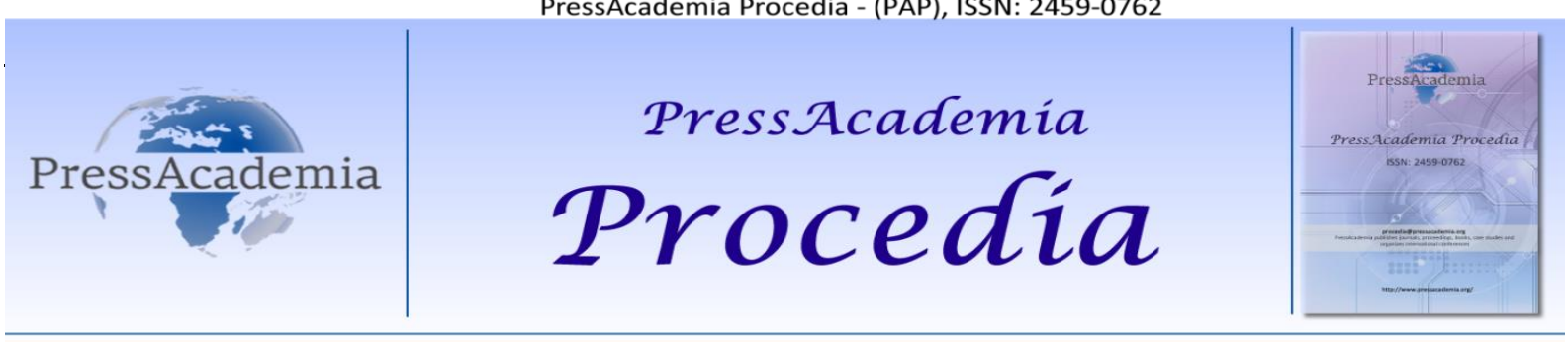

Global Business Research Congress (GBRC), May 24-25, 2017, Istanbul, Turkey.

\title{
INTEREST- FREE BANKING: REASONS FOR CHOOSING ISLAMIC BANKING IN BINGOL CITY
}

\author{
DOI: 10.17261/Pressacademia.2017.411 \\ PAP-GBRC-V.3-2017(26)-p.257-268
}

\section{Imran Aslan}

Bingöl University, Healthcare Faculty,,Bingöl,Turkey, imranaslan@gmail.com

\section{To cite this document}

Aslan, I. (2017). Interest- free banking: reasons for choosing Islamic banking in Bingöl cit. PressAcademia Procedia (PAP), V.3, p.257-268 Permemant link to this document: $\mathrm{http}: / /$ doi.org/10.17261/Pressacademia.2017.411

Copyright: Published by PressAcademia and limited licenced re-use rights only.

\begin{abstract}
Participation banking (Interest Free Banking)/Islamic Banking (IB) is a current topic in Turkey and in many Muslim countries. In Hammurabi's law and Babil's documents in 1955-1913 BC, interest and usury were forbidden to protect the community. Participation banking is explained in this study and compared with interest orienting conventional banking system. A questionnaire method was used as a data collection tool in Bingöl city in East of Turkey in 2015. 500 customers of Turkey Finance Bank in Bingöl were surveyed and obtained data was analyzed through IBM SPSS 20 Software. Frequency-analysis method, descriptive statistics and ANOVA methods were used to analyze collected data. According to these findings, it can be said that participating banking is usually preferred among $20-40$ age group. Also, it is stated that participants use participating banking less than 6 years. The reason why they select participation banking is as; close relationship with branch personnel, leading religious sensibility, friendly and helpful personnel, image and popularity of banking, Islamic Audit Commission of bank. As the age of participants increase, they have more positive thoughts on participation banking. Moreover, there is a high suspiciousness that IB is applied as conventional banking, making it also Haram.
\end{abstract}

Keywords: Interest-free banking, Islamic Banking, Participation Banking JEL Codes: E5,G2, B27

\section{INTRODUCTION}

Islamic Banking (IB) is explained by Profit-and-Loss Sharing (PLS) paradigm based on mudarabah (profit-sharing) and musyarakah (joint venture) concepts. Islamic Banks have Shariah advisory committees to control religious obligations according to Islam religion. The Shariah (Islamic law) governs every aspects of Muslims. Non-halal investments are forbidden in Islam such as the sale of alcohol, pork, and tobacco, gambling and prostitution and also gharar (uncertainty and risk) investments and taking or offering riba. ( Chong \& Liu, 2009)

To learn the opinions of IB costumers and awareness level, a survey was applied to main Islamic Banking costumers (Turkiye Finans Bank) in Bingöl city. Bingöl city people are known with their conservative life style and Islamic views and decisions. The city has long conservative Islamic view story and people are categorized as conservative when compared with other cities in Turkey in generally. Hence, high rate of IB usage and awareness are expected in the city. They city center has 106 thousand people and the overall population of city is about 300 thousand people. Thus, the city is expected to be a hub for IB in future. The major disadvantage of city is being in East of Turkey and having low industry and job opportunities. Many people leave their families and go other developed cities in Turkey to work temporarily. People living in city are mainly governments' officers, or work in farming and service sector. Moreover, the education level is not at expected level and 
many people born in the city immigrated to other developed countries especially Europe like Germany. Some of these people send some amount of money for their families to sustain their lives. The bad security image prevents the city from taking foreign investments and the infrastructure is not at developed level to make big investments. Hence, these factors prevent people to have more money for investments since more earnings can allow people to make more savings.

\section{LITERATURE REVIEW}

It is estimated that the total asset of Islamic finance was about 2 trillion USD by the end of 2014. (Wankea et al. , 2016) Only IB is allowed in Iran, Pakistan and Sudan from 50 Muslim countries while IB and conventional banking co-exist in Turkey, Bangladesh, Egypt, Indonesia, Jordan and Malaysia. Moreover, IB exists in some non-Muslim countries like England as Islamic Bank of Britain opened in 2004 and also the HSBC and University Bank in Ann Arbor and Devon Bank in Chicago offer IB products in the United States. (Chong \& Liu, 2009) Toxic assets based on interest and debt-selling activity and not comply IB are found the main causes of the global crisis. (Alqahtani et all., 2016) Global banking system has lost the confidence of costumers due to 2008-2012 global financial crises. (Akbar et all., 2012) It is found that IB with a grow of 20 $\%$ per annum in the World performed better in the early stages of global financial crisis in terms of capitalization, profitability and liquidity in the time of economic shocks over the period $1998-2012$. The growth rate of IB is $25 \%$ per annum during the years 2000 and 2012 in gulf countries with the expansion of oil and gas development and production. However, after the 2014 drop in oil prices, the IB grow rate has decreased in these countries. (Alqahtani et al., 2016)

Afterlife utility concept is a religious concept dealing with expenditures for the present life and for the afterlife such as donating to the needy people. People expect high return with high risk investments but, they prefer low returns in accordance with their believes. Riba(Interest) has severe afterlife punishment according to Islam religion. Channeling savings of Muslims to IBs with an additional utility gain can increase the welfare in most Muslim countries. (Kumru \& Sarntisart, 2016) "Ijara" purchasing an asset and leasing it to a client, "Mudaraba" a contract being entered into between an IB and a client by providing all the capital a client needs for an enterprise to get a share of profit, "Musharaka" providing a proportion of the capital in addition to management and know-how by client, and "Murabaha" purchasing goods, raw materials, equipment, machinery etc. at economic significance from a third party at the request of a client to sell the client on a spot or deferred payment basis; In that contract, IBs buy and sell assets instead of costumers are kinds of products in IBs. They are derived according to Qur'an and the Sunnah (tradition or practice of Prophet Muhammad (SAW) in the realm of the Muslim socioeconomic system. (Saiti, 2015; Aysan et all., 2016) Islamic finance has real assets or leasing assets with losing risk of them than conventional financial products, forcing IBs to choose less risky projects. However, it cannot guarantee a deposit and there is the risk of losing invested money in bank in case of bankruptcy. Uncertainty creates asymmetric information problems that costumers want to know different expected profit and loss making states and the associated probability of each occurring. Lending to reputable borrowers, long-term funding relationships and threat of prosecution are ways of banks to decrease the risk and moral hazards like under-reporting profit. Staged financing such as giving a small amount of fund at the beginning and additional funds subject to specific performance targets, active monitoring and controlling of board and voting rights to replace poorly performing managers are methods used to overcome moral hazards by banks. (Brownet all., 2015) Islamic financial institutions are more risk-averse by allowing borrowers to select low-risk projects. The motivation for the prohibition of interest is to protect poor people and to decrease income inequality. There is a higher level of funds mobilization, economic growth and poverty alleviation for medium-size Islamic banks in low income countries. (Abedifara et all.,2016)

"The name of the banks had been changed to reflect that it was an Islamic-based bank whereby the interest, which is prohibited in Islam, was still practiced" definition were come out from Malaysian study in 2000. Vagueness was the main problem on IBs concepts in Malaysia. Being aware of the profit and loss sharing concept by investors and education of IBs workers can handle these problems. (Buchari et al., 2015) Not operating under the PLS system and only follow the traditional interest based system with different names is one of the ethical problem causing distrust for Muslims in UK with absence of stronger regulation of IBs practices. (Akbar et all., 2012) Bing more efficient, better performing, and less risky than conventional banks can increase the popularity of Islamic banks. For not being sufficiently ethical and transparent is the major problem increasing critics. IBs are less significant in countries in which conventional banks and IBs exist together. Confusion between Islamic finance and Islamist matters make differences in IBs from country to country. Besides decreasing oil prices and the $9 / 11$ shock in the United States can be seen as exogenous variables affecting the opportunities of IBs around the world. The Middle East with huge IBs potentials has the highest profitability while South Asia IBs have the lowest profitability. Control by the authorities of the Sharia board changes according to performance level while at high performance, the Sharia board was activated to control status of investments with asymmetry according to regions by using daily data on 12 Islamic banks in four regions (Africa, Asia, Europe, and the United States) from July 2007 to April 2016. (Jawadi et all., 2017)

It is found that IBs have higher capital making the returns of Islamic banks more volatile, liquidity and profitability and volatile earnings than conventional banks through using data from 8, 615 banks (including 123 Islamic banks) in 124 
developed and developing countries for the period between 2006 and 2012 that higher liquidity decreases the profitability of conventional banks. (Bitar et all., 2016) Also, the quality of services between Islamic and conventional banking is a crucial factor affecting the costumer of IBs. Branches or easy reach, behaviors of staffs, bank administrative fee of their account, charge administration fee when making transactions etc. are kinds of services to attract more customers in IB. (Wulandari \& Subagio, 2015) According to CAMEL: (C)apital adequacy, (A)sset quality, (M)anagement efficiency, (E)arnings and (L)iquidity for the 101 banks from the six Gulf Cooperation Council (GCC) economies states from 1998 to 2012, Qatari Islamic banks outperformed better than conventional banks in terms of asset quality, management quality, earning and liquidity, which can be due to high oil incomes. (Alqahtani et all., 2016) Riba (27.2\%); Shariah (33.6\%); Mudharabah (19.8\%); Musharakah (19.8\%); Sukuk (16.4\%); Takaful (28.4\%); Murabaha (18.1\%) and ljarah (22.8\%) are terms from respondents that they understand from Islamic banking products/terms in Mauritius on the customers' awareness of IB in $2013.66 \%$ of the respondents are motivated by religious beliefs only while majority of respondents by $84 \%$ had impression on Islamic bank's return. (Buchari et all., 2015) Furthermore, it is found that learning curves of IBs is low since there is not a hard competition in their field based on 114 Islamic banks from 24 countries using the Technique for Order Preference by Similarity to the Ideal Solution (TOPSIS) method. TOPSIS can be managed by implement continuous improvement programs on their operations of banks with European and Persian Gulf origins.( Wanke, 2015 ) A sample of 150 Muslim and nonMuslim customers in Klang Valley in Malaysia was applied to learn important factors affecting selecting IBs that Muslims are more aware about IBs Riba term is the most known one in IBs with $85.9 \%$ from 92 Muslim respondents while Riba and Shariah are the most known terms for non-Muslims with $20.7 \%$ from 58 respondents. ljarak, mudarabah, Musharakah and Murabaha are terms known less than $50 \%$ of Muslims and almost not known terms by non-Muslims. For non-Muslims, the main criteria to select an IB are profitability and will withdraw their money in any case of low profit while Muslim costumers retain their deposits. Convenience (i.e. the location), friends' recommendations, reputation of bank, availability of credit, competitive interest rates, friendliness of bank staff, service charges, adequate banking hours, availability of ATM, special services and the quality of services on checking accounts are main criteria to select a bank. (Saiti, 2015) A sample of 290 Indian Muslims in Delhi NCR region of India showed that majority of the respondents are lacks of understanding of IBS structure, which can be due to the non-availability of any established Islamic banks and also they are willing to use IB if they are properly communicated. Informative advertising campaigns can be used to get more IBs costumers in India. India is a good example of Muslim \& Non-Muslim mixed market with 172 million Muslim people to provide delivering personalized and customized products and services. Foreign investments especially from Gulf Cooperation Council countries can enter this market to expand IBs market. (Rahman , 2017) Moreover, this market can be a potential for Turkish IBs with growing interest of banks in that field recently in Turkey.

It is found that the efficiency of the Malaysian Islamic banks is lower than USA and European banks efficiencies due to cost structure having a prominent negative impact on efficiency levels and cultural and regulatory barriers. (Wanke et al., 2016) Awareness about Islamic banking products and advertisements, Islamic contracts and PLS concept; Perceived Values such as having big role in eliminating poverty, serving low income community and fulfilling the banking needs of Muslims in Dagestan; Attitude like being more shariah compliant, more profitable, flexible and beneficial and being fair; Subjective Norm such as supporting engagement with IB through valued people, and aiming to use IB and Intention to Perform IB variables are used from 400 respondents in $85 \%$ Muslim region named as Dagestan/Russia that it is found that awareness has a positive influence on intention to support IB trough attitude by structural equation model (SEM) method of the Theory of Reasoned Action model. Only $6 \%$ of respondents are familiar with Islamic banking products and advertisement while $38.8 \%$ of them are less familiar and $49.5 \%$ of them are not familiar with IBs.(Abduh \& Idrisov , 2014)

The liberalization period has started since 1980s in Turkey by integrating more to the global financial system, improving its financial technology and human capital and relaxing of regulatory barriers and it is found that the efficiency have increased after that period. Albaraka Türk Finans Kurumu (Albaraka Turk Finance House) and Faisal Finans Kurumu (Faisal Finance House), Kuveyt Türk Finans Kurumu (Kuwait Turkish Finance House), Anadolu Finans Kurumu (Anadolu Finance House), Ihlas Finans Kurumu (Ihlas Finance House), and Asya Finans Kurumu (Asya Finance House) are types of IB entered in Turkey's financial sector without having the same status as conventional banks. Until 2005 there were strong criticizes that these banks were not different from conventional banking but after 2005 legislative changes, a more explanatory system was developed to operate without any discrimination. Transforming deposits into productive capital defines the efficiently of banks. It is found that IB depositors named as investors rather than creditors reach strongly to interest rate changes in Turkey and It is stated in some studies that IBs make operations as conventional counterparts in creating their assets through non-PLS methods, making doubt on the uniqueness of IB. Fear of losing depositors in Islamic banks causes to offer similar rates to those of conventional deposits. As the risk of Islamic banks increase, deposit withdrawals can be done by shareholders in IB. During the collapse of Ihlas Finans Kurumu (ihlas Finance House) operated on Islamic principles in Turkey, depositors drew their money rather than sharing the losses in 2000-2001 years, showing that depositors were not ready to share the burden of monetary policy changes as the PLS. Savings Deposit Insurance Fund, Tasarruf Mevduatı Sigorta Fonu in Turkish provided insurance up to 50,000 TL and it is at the depositors' own risk over this amount. It is found that only the largest depositor groups in conventional banking response interest changes. Islamic banking customers 
are more sensitive to interest changes and non-sensitive IB depositors are smallest deposit group (0-10 thousand TL). (Aysan et al., 2017)

The financing gap for Small and Middle Size Enterprises(SMEs) being able to be managed more effectively through Islamic banks by enabling environment for risk-sharing in Turkey resulting in higher SME financing growth rates, and having a higher share of SME financing in their financing portfolio for four Islamic banks (Türkiye Finans, Albaraka Turk, and Kuveyt Turk) is clear sign of Banks' willingness to finance SMEs based on a unique quarterly small business panel data set of 40 commercial banks from 2006 to 2014. (Aysan et al., 2017) 270 micro-entrepreneurs and petty traders in 3 major cities of Pakistan including Rawalpindi, Lahore and Peshawar and 100 people from five IBs middle and top management in Islamabad and Lahore were surveyed that micro-entrepreneurs and petty traders are in favor of Islamic microfinance under a system of PLS and they criticized governments for not encouraging the establishment of Islamic microfinance to the low-income class and the current given money is not enough to improve their life and business. Moreover, majority of the Islamic bankers and regulators think that IB is a powerful way of fighting poverty. Low-income people or those who rejected interest-based debt can be supported by Islamic microfinance to improve economic status. Lack of appropriate knowledge, experience and professionalism of staffs, not well developing the present structure for the implementation of Islamic microfinance because of some constraint such as lack of supervision by central bank and lack of supporting institutions, moral hazard and lack of adequate loanable funds based on profit and loss sharing are major problems of this system. (Abbas \& Shirazi , 2015) Around $20.7 \%$ of micro-enterprise owners in Algeria and around $49 \%$ of the rural population of East Java in Indonesia prefer Sharia-compliant financial products and services that interest is prohibited in Islam. (Abedifara et al.,2016) These cases can be an example for Turkey to support IBs for financing micro-entrepreneurs and petty traders. Muslim people want to get more money for their SMEs in Halal way and expand their business. Moreover, high rate of unemployment in Turkey can be decreased in that manner. There are some micro-financings already by governments. However, the effective usage of these funds and transparency are questionable due to frauds happening while distributing funds.

Treating customers politely and with respect, staff ability to uphold trust and confidence, effectiveness and efficiency in handling transactions, and competency of staff in handling customers' banking needs are factors for the quality of banking services. Waiting time, IB building \& room, accuracy of recording, knowledgeable and experienced management team, the ability to listen to customer complaints, interest free loans, number of enough counters, available parking space nearby etc. are parts of operational variables while compliance, assurance, reliability, tangibility, empathy, and responsiveness are to be considered in IBs as done in other banking types. (Maswadeh , 2014) From a survey of 192 employees at Islamic banks in Malaysia, the fairness of organization having a positive effect on Organizational Citizenship Behavior (OCB) named as "helping the organization to sustain in the future effectively, efficiently, and competitively by adopting a set of moral, constructive, and positive behaviors that transcend employees' formal job requirements" may help sharing information with their colleagues, reporting ethical problems, and having a positive image about the organization like salaries, rewards, promotions, etc. Being fairly among employees can help employees to increase their organizational commitment. Islamic Work Ethic (IWE) "a set of moral principles prescribed in the Quran and Sunnah that guides employees' attitude and behaviors at their workplace" are important for IBs success to standardize IB in all Muslim countries. (Mohammad et al.., 2016 ) Religious beliefs than profitability was preferred from study done in Bahrain in 1998 and in 2009 on 296 Libyan business firms on attitudes towards Islamic finance and a study on Muslim businessmen in Malaysia in 2007 with $80 \%$ against $58 \%$ of the users for profitability. Hence, religious conviction is the key to get more deposits in the country. (Buchari et al., 2015) Survey among around 100 executives and entrepreneurs in the Sultanate of Oman showed that Islamic norms are to be followed rather than only satisfying the customers. Education programs focusing on inculcating entrepreneurship goals in young minds can help the country to grow in future with IBs fundamentals such as "Banking activities should not harm society", "bringing together business women to benefit from each other's business expertise and experience". Islamic values perspective, social perspective, ethical obligations, transparency and sustainability, financial orientation, employment opportunities and contemporary and blending of values and customer preferences are factors to be concentrated in order to promote IB with increasing acceptance. (Subramaniam \& Krishan, 2014)

\section{DATA AND METHODOLOGY}

The main population of this study is about 10,000 costumers having IB account in Bingöl city. The questions used in the survey were created by using the works of Buchari, Rafiki \& Qassab (2014), Khattak, Ur-Rehman (2010) and Naser, Salem \& Nuseibeh (2013) studies. About 500 costumers (5\% of main population) significant statistically to represent the main population were surveyed. Survey is composed of three sections: In the first part of the questionnaire, a number of questions were asked to measure the demographic information of the participants. These questions measure the age, education, monthly income, marital status, occupation, the number of years in participation banking, and the number of participation accounts in the bank. In the second part of the questionnaire, the reasons for choosing Islamic/ participation banking are tried to be found. For this aim, participants were asked such as "Why do you choose Islam / 
Participation Banking?" with how effective each of the 24 items given under the question. In the third part of the questionnaire, participants were asked to identify their views on IB. The responses to the items are likert type of $5(1=$ Very effective, 2 = Effective, $3=$ No stimulus, $4=$ Not effective, $5=$ Not effective at all) . The Cronbach's Alpha is 0.87 for all items that the survey items have high reliability.

\section{ANALYSIS AND FINDINGS}

$67 \%$ of respondents are under 35 years old and $47 \%$ of them are under 30 years old. Hence, it can be said that the majority of IB in Bingöl are mainly young costumers while just $10 \%$ of them is greater than 40 years old. $38.8 \%$ of them have primary school education degree and just $5.8 \%$ of them have master degree. The average salary of them is about $3,000 \mathrm{TL}$ and $71.2 \%$ of them are married hence the average salary of them is middle level since the minimum salary of an employ is about 1400 TL in Turkey while $47.8 \%$ of them have $1300-2300$ TL salary. $81.1 \%$ of them are tradesmen and just $10 \%$ of them are officers that the Islamic thinking is strong at city among IB costumers with high tradesmen costumers.

Table 1: Demographic Factors

\begin{tabular}{|c|c|c|c|}
\hline Group & Parameter & Frequency & Percent (\%) \\
\hline \multirow{6}{*}{ Age } & $20-25$ & 127 & 25.4 \\
\hline & $26-30$ & 108 & 21.6 \\
\hline & $31-35$ & 105 & 21.0 \\
\hline & $36-40$ & 110 & 22.0 \\
\hline & $41+$ & 50 & 10.0 \\
\hline & Total & 500 & 100.0 \\
\hline \multirow{6}{*}{ Education } & Primary Education & 147 & 29.4 \\
\hline & High School & 194 & 38.8 \\
\hline & Pre-Undegraduation (2 years program) & 96 & 19.2 \\
\hline & Undergraduate & 33 & 6.6 \\
\hline & Master & 29 & 5.8 \\
\hline & Total & 500 & 100 \\
\hline \multirow{5}{*}{ Salary(TL) } & $1300-2300$ & 239 & 47.8 \\
\hline & $2301-3300$ & 112 & 22.4 \\
\hline & $3301-4300$ & 106 & 21.2 \\
\hline & $4301+$ & 40 & 8.0 \\
\hline & Total & 500 & 100.0 \\
\hline \multirow{3}{*}{ Social Statue } & Married & 356 & 71.2 \\
\hline & Single & 134 & 26.8 \\
\hline & Total & 500 & 100 \\
\hline \multirow{8}{*}{ Occupation } & Tradesman & 406 & 81.2 \\
\hline & Officer & 50 & 10.0 \\
\hline & Accountant & 3 & 0.6 \\
\hline & Student & 20 & 4.0 \\
\hline & Teacher & 7 & 1.4 \\
\hline & Painter & 6 & 1.2 \\
\hline & Self-employment & 8 & 1.6 \\
\hline & Total & 500 & 100.0 \\
\hline
\end{tabular}

$32 \%$ of costumers are new costumers of IB by using it less than a year and $41.2 \%$ of them use IB between $1-3$ years. The average of using IB is about 2.3 years by considering 6 years as the max usage and just $1.8 \%$ of them use the IB more than six years. Moreover, $57.1 \%$ of them have also an account in conventional banking in other banks. The main reasons of using IB are "Image and popularity as a participation bank and interest-free institution" with 1.37 mean, "My investment is not put in other banks or companies" with mean of 1.53, "The Bank follows Islamic rules" with mean of 1.59, "Orientation of my religious sensitivities" with 1.66 mean, "Close relationships with branch staff" with mean of 1.93, "Friendly and helpful staff" with mean of 1.94 and "The checks/controls made by the state (due to Islamic conformity) are sufficient" with mean of 1.98 while a more attractive and unusual banking, high quality suggestions done by staffs, a service approach that 
satisfies customer expectations, attractive product, process and service tariffs, product and service variety and not sharing personal data and accounts with third parties are the least important factors on choosing IB of Turkey Finance Bank in Bingöl city as shown in Table 2.

Table 2: Means of Items

\begin{tabular}{|l|l|}
\hline Why do you choose IB? & Mean \\
\hline Close relationships with branch staff & \\
\hline Orientation of my religious sensitivities & 1.9360 \\
\hline Friendly and helpful staff & 1.6620 \\
\hline Regard and respect for people & 1.9480 \\
\hline Knowledgeable and skilled staff & 2.1980 \\
\hline Peaceful working environment & 2.2440 \\
\hline A service approach that satisfies customer expectations & 2.5080 \\
\hline Image and popularity as a participation bank with interest-free institutions & 2.8640 \\
\hline A more attractive and unusual banking & 1.3780 \\
\hline Customer service quality (Fast. efficient and error-free service) & 2.9840 \\
\hline Banking image and popularity & 2.6200 \\
\hline Successful banking and finance management & 2.7260 \\
\hline Trustworthy friends or environmental advices & 2.7200 \\
\hline Some services and facilities not provided by other banks & 2.4680 \\
\hline Attractive product, process and service tariffs & 2.6700 \\
\hline Convenience, convenient accessibility (eg vehicle parking facilities. comfort. etc.) & 2.8320 \\
\hline Relatively higher dividend distribution & 2.7960 \\
\hline Attractive credit and payment conditions & 2.6360 \\
\hline Product and service variety & 2.8200 \\
\hline Ads in mass communication tools & 2.7240 \\
\hline Low transaction / service fees & 2.7220 \\
\hline Islamic Supervision Board of the Bank & 2.0020 \\
\hline The same offers are done by Islamic bank / participation as commercial banks & 2.6400 \\
\hline Home and workplace closeness & 2.7480 \\
\hline The Bank follows Islamic rules & 1.5920 \\
\hline I trust the management of the bank & 2.2440 \\
\hline My personal data and accounts are not shared with third parties & 2.8120 \\
\hline Services provided in participation banking are more qualified & 2.7260 \\
\hline Participation banking suggestions is highly qualified by the staff & 2.9520 \\
\hline Controls made by the state (due to Islamic conformity) are sufficient & 1.9860 \\
\hline My investments are not made in other interest based banks or companies & 1.5331 \\
\hline
\end{tabular}

According to the results of the One-Way ANOVA analysis, the main reason for choosing the IB system for "Friendly and helpful staff" item is significantly different among the ages of participants item with $F(4,495)=9,275 ; P<0.05$ value. Accordingly, participants in the age range of 36-40 years showed significantly less importance to this item compared to other age groups. For "Regard and Respect for Humanity" item, participants in the 26-30 and 36-40 age group showed significantly less importance to this substance than the other age groups. For "A more attractive and unusual banking" item, it is seen that the participants over 41 years gave this item significantly more importance than the other age groups. For "Customer service quality (Fast, efficient and error-free service)"item, it is seen that the participants over 41 years gave this item significantly more importance than the other age groups. For "Some services and facilities not provided by other banks", it is seen that the participants over 41 years gave this item significantly more importance than the other age groups. "Attractive product, process and service tariffs" item, according to this, it is seen that the participants over 41 years gave this item significantly more importance. "The same offers offered by a commercial bank offer also by Islamic bank / participation" item, it was seen that the participants in the age range of 31-35 years and 41 years gave significantly more important in this item. "Home and business proximity" item, accordingly, participants in the age range of 26-30 years and over 41 years showed significantly less importance to this item as shown in Table 1 in Appendix section for other significant items for age. 
Table 3: ANOVA According to Education

\begin{tabular}{|c|c|c|c|c|c|c|}
\hline & Education Level & $N$ & M & SS & $\mathbf{F}$ & p \\
\hline \multirow{5}{*}{$\begin{array}{l}\text { Islamic Supervision Board of } \\
\text { the Bank }\end{array}$} & Primary Education & 147 & 2.18 & 1.20 & \multirow{5}{*}{3.750} & \multirow{5}{*}{0.005} \\
\hline & High School & 194 & 2.10 & 1.26 & & \\
\hline & $\begin{array}{l}\text { Pre-Under graduation ( } 2 \text { years } \\
\text { program) }\end{array}$ & 33 & 1.74 & 0.78 & & \\
\hline & Undergraduate & 96 & 1.64 & 0.87 & & \\
\hline & Master & 29 & 1.76 & 0.95 & & \\
\hline \multirow{5}{*}{$\begin{array}{l}\text { The same offers are done by } \\
\text { Islamic bank / participation as } \\
\text { commercial banks }\end{array}$} & Primary Education & 147 & 2.65 & 1.27 & \multirow{5}{*}{2.512} & \multirow{5}{*}{0.041} \\
\hline & High School & 194 & 2.63 & 1.22 & & \\
\hline & $\begin{array}{l}\text { Pre-Under graduation( } 2 \text { years } \\
\text { program) }\end{array}$ & 33 & 2.72 & 1.22 & & \\
\hline & Undergraduate & 96 & 2.06 & 1.36 & & \\
\hline & Master & 29 & 3.03 & 1.45 & & \\
\hline \multirow{5}{*}{$\begin{array}{l}\text { I trust the management of the } \\
\text { bank }\end{array}$} & Primary Education & 147 & 2.27 & 1.54 & \multirow{5}{*}{2.655} & \multirow{5}{*}{0.032} \\
\hline & High School & 194 & 2.12 & 1.23 & & \\
\hline & $\begin{array}{l}\text { Pre-Under graduation ( } 2 \text { years } \\
\text { program) }\end{array}$ & 33 & 2.29 & 1.31 & & \\
\hline & Undergraduate & 96 & 2.91 & 1.26 & & \\
\hline & Master & 29 & 2.07 & 1.10 & & \\
\hline
\end{tabular}

According to the results of the one way ANOVA analysis, it was seen that the subjects given the reasons for selecting the Islamic / Participation banking differ significantly according to the educational status of the subject as shown in Table 3. According to "The Bank's Islamic Supervision Board", it has been seen that primary and high school graduates have significantly less importance on this item compared to other age groups. The main reason for the "Making the same offers by an Islamic bank / participant as a commercial bank " was found to be significantly different according to the educational status of the participants. Master respondents have high mean with 3.03 that the bank has better offers while undergraduate respondents are completely sure /neutral about that item. High school students has the lowest trust on management of IB with significant differences. Undergraduates participants have the highest trust with 2.91 in IB in Bingöl while master graduates have the lowest trust. Respondents between salary of 3301-4300 TL think that staffs and management of IB show mores respect and low salary costumers have lowest mean for respect and regard item. Besides that item, 19 items are significantly different according salary groups through one way ANOVA. Moreover, good working environment, the image and popularity of IB, variety of products and services, add with mass media, low transaction costs, proximity to work and home, and not sharing personal information with third parties are significantly different according to social status.

\section{DISCUSSION, LIMITATION AND FUTURE RESEARCH DIRECTIONS}

According to study of Chong \& Liu ( 2009) in Malaysia IB is not very different from conventional banking based on "changes in conventional deposit rates cause changes in Islamic investment rates, but not vice versa" , "the Islamic investment rates are positively related to conventional deposit rates in the long-term" and "when the Islamic investment rates deviate far above (below) the conventional deposit rates, they will adjust downwards (upwards) towards the longterm equilibrium level" results from their study. Moreover, they think that any capital relief for assets funded by mudarabah deposits may not be suitable for IB. The proper control of entrepreneurs is necessary that they obey Islamic rules and PLS financing. Respondents with high school and masters degrees have low trust the management as this study. However, following Islamic rules is effective factor for respondents to choose IB and the main reason for choosing IB is being an interest-free institution. Hence, the transparency of IB in Bingöl city is to be provided that people know that their investments are not put in Non-Halal investments. (Chong \& Liu , 2009)

Issues of poverty and environmental tragedies are not included in the Muslim World economic models and calculating tax (zakat) as stated in study of Kamla \& Alsoufi( 2015), "halal" products and design Profit-Loss sharing contracts are not well studied at universities in Turkey. Not creating same profit levels of conventional banking and finance counterparts is the main problem of IB and thus they cannot compete with conventional banking system. Thus, a unique Islamic accounting or 
economic model is necessary not just for Muslim countries but also for non-Muslim countries within global vision to increase the competitive ability of IB especially in dual-system countries. According to Okumus (2005), 75\% of respondents trust IB with fulfilling Islam's requirements. Religion and profitability are main reasons, "if there is no profit for depositors, they will keep their deposits with Islamic banks" item is studied in past studies and it is found that just $44.9 \%$ of Muslim participants agree on that item. In Muslim countries, costumers have basic knowledge about Islamic banking services and products and financing from Libya and Brunei Darussalam studies done in different years 2009 and 2013 respectively. Moreover, just 50\% of respondents from Kazakhstan were aware of IB and majority of Muslims are willing to patronize Sharia based products and services. (Abduh\& Idrisov, 2014) Hence, higher levels of awareness can increase the opportunity of using IB. Differences between conventional and Islamic Banks are not well known in many Muslim countries since, the same bank has both IB and conventional banking as happened in Turkey and this questions the halal status of bank by doing halal and non-halal transactions at the same time.

Unwillingness to put their savings into a traditional financial system for Muslims can be a financial lost. Islamic banks are profit-maximizing entities acting as intermediaries between savers and investors. Uncertain contracts such as undertaking a business venture without sufficient information or taking excessive risk are banned in Islamic banking. Moreover, Islamic banks have to distribute some part of its profit as Zakat to community under some rules. For Muslim countries with proper legislations, regulations and supporting infrastructure, Islamic bank can be beneficial for growth. It is also advisable for nonMuslim countries to reduce the probability of crisis since excess leverage, use of derivatives, securitization of sub-prime loans can not be allowed in that system. (Patrick \& Kpodar, 2016) 387-401; Jawadi et al., 2017) Severe 2007-2009 financial crisis due to the collapse of investment banks largely and loss of confidence in mortgage credit market in the United States has shifted the attention to Islamic Banking claimed to be resilient to shocks due to its inherent stability as an alternative and without riba (usury) and maysir (gambling). It is found that the overall technical efficiency scores of the Islamic banks in Asian countries is greater than in the Middle Eastern countries IBs. (Rosman et al., 2014) Islamic economy based on calculating tax (zakat), halal products and design PLS contracts are to be developed and taught at schools and especially at universities to increase the awareness among all Muslim countries and Non-Muslim countries having Muslim communities. Moreover, it should be a right of Muslims living non-Muslim countries having the knowledge about Islamic way of their investments.

\section{CONCLUSION}

The aim of establishing IB in Turkey is to add financial values that are not included in the economy in the framework of interest-free financing principles and to improve the relations with Islamic countries and transfer the resources of these countries rich in oil to Turkey. It can be argued that these banks have realized these aims in a considerable extent when the increased number of branch-personnel and total deposits are examined. The financial crisis that the world economy experienced in 2008 has brought the importance of Islamic finance instruments to the forefront and has increased the use of various Islamic finance instruments. As a result of studies, especially the complexity of structures that act as an intermediary between the borrower and the lender increases, transactions are carried out at high leverage ratios, and thus conventional financial system is subjected to intense criticism in this context. The advantages of the interest-free finance model in this frame are that the financial assets grow together with the real economy, the speculation is not allowed, and the social and moral responsibilities in investment decisions are taken into consideration. In the theoretical manpower, the Islamic finance system is funded by equity. For these aims, some governmental supported strong banks as Vakif Bank and Ziraat Bank in Turkey opened IB branches around the country. As stated, the main aim is to bring "Under the pillow money" to the economy and increase their profit.

The majority of the participants earned between 1300-4300 TL per month while the number of participants who earned more than $4300 \mathrm{TL}$ per month was found to be less than the other groups. It appears that the vast majority of the participants are married and tradesmen. From the professional point of view, it is seen that the greatest majority after the trades are officers. It has been determined that the number of participants using IB which is longer than 6 years is very small.

Participants think that about almost all the reasons for choosing IB are effective. For these reasons, it was seen that the options with the highest scores were "close relations with branch personnel", "directing my religious sensitivities", "friendly and helpful personnel", "banking image and popularities" and "the Bank's Islamic Supervisory Board". None of the options have been described as "not effective" by the participants. In other words, the answer choices "not effective" and "not at all effective" did not occur in any of the majorities. Participants' most frequently agree on "Bank is in line with the rules of Islam," "State controls are adequate", and "My investment is not being made in other banks or companies."

In addition to these, the reasons for choosing participants' IB according to their demographic variables are examined. According to the results, it was determined that participants over 41 years gave more importance to majority of reasons of choosing IB other age groups. Generally speaking, as the age of the participant increases, the importance given to the 
reasons of choosing IB has increased. In addition, when the monthly incomes of the participants are examined, it is seen that the middle income participants with a monthly income between 2031-3000 TL gave less importance to choosing IB than the other participants. As the monthly income increases, it is seen that the importance given to these reasons increases even more. From there, it can be interpreted that people are choosing the bank more precisely when they increase their income. Looking at the marital status of the participants, it was seen that single participants paid more attention to choosing IB than married participants. When the professions of the participants were examined, it was determined that the tradesmen gave less importance to the bank selection than the other occupational groups. Although there are some meaningful results when the educational status of the participants is considered, they are not at a level that interpretation and generalization can be made on the results. However, more educated costumers have lest trust on IB that they apply total Islamic rules.

\section{Acknowledgements}

I want to give my special thanks my master student Ebru Ataoğlu for helping to carrying out surveys.

\section{REFERENCES}

Akerlof, G.A., (1970). The market for lemons: quality uncertainty and the market mechanism. Quarterly Journal of Economics, vol. 84, no. 3, p. $488-500$

Alessandri, T., Cerrato, D., Depperu, D. (2014). Organizational slack, experience and acquisition behavior across varying economic environments. Management Decision, vol. 56, no. 5, p. 967-982.

Abbas K.\& Shirazi N.(2015) "The key players' perception on the role of Islamic microfinance in poverty alleviation: The case of Pakistan", Journal of Islamic Accounting and Business Research, Vol. 6 No. 2, pp. 244-267, DOI 10.1108/JIABR-06-2013-0017.

Abduh M. \& Idrisov M.( 2014) "The Role of Awareness and Perceived Values upon the Acceptance of Islamic Banking and Finance in Dagestan", Journal of Islamic Banking and Finance, July- Sept., pp.50-60.

Abedifara P., Hasan I. Tarazi A.( 2016) "Finance-growth nexus and dual-banking systems: Relative importance of Islamic banks", Journal of Economic Behavior \& Organization, 132 , p.198-215.

Alqahtani F., Mayes D.G. \& Brown K. (2016) "Economic turmoil and Islamic banking: Evidence from the Gulf Cooperation Council, PacificBasin Finance Journal , 39 , p. 44-56

Akbar S., Shah S.Z.A. , Kalmadi S. (2012),"An Investigation of User Perceptions of Islamic Banking Practices in the United Kingdom", International Journal of Islamic and Middle Eastern Finance and Management, Vol. 5 Iss: 4 (Date online 23/10/2012)

Aysan A.F. , Disli M. , Ng A. \& Ozturk H. (2016) "Is small the new big? Islamic banking for SMEs in Turkey", Economic Modelling, 54 .

Aysan et al.(2017) "Religiosity versus rationality: Depositor behavior in Islamic and conventional banks", Journal of Comparative Economics (2017), http://dx.doi.org/10.1016/j.jce.2017.03.001.

Bitar M., Madi P., Taramasco O.(2016) “What makes Islamic banks different? A multivariate Approach", Economic Systems , http://dx.doi.org/doi:10.1016/j.ecosys.2016.06.003.

Brown K., Azmat S., Skully M. ( 2015) “Can Islamic banking ever become Islamic?”, Pacific-Basin Finance Journal, 34 , p.253-272.

Buchari I. , Rafiki A. , Qassab M.A.H. (2015) "Awareness and attitudes of employees towards islamic banking products in Bahrain” 3rd Economics \& Finance Conference, Rome, Italy, April 14-17, 2015 and 4th Economics \& Finance Conference, London, UK, August 25-28, 2015.

Buchari I., Rafiki A. \& Qassab M. A.H. (2014), "The Employees' Awareness and Attitudes Towards Islamic Banking Products: a Survey of Islamic Banks in Bahrain", World Applied Sciences Journal, 32(3), pp.436-443.

Chong B.s.\& Ming-Hua Liu M.(2009) “Islamic banking: Interest-free or interest-based?”, Pacific-Basin Finance Journal, 17, p.125-144.

Imam P.\& Kpodar K.(2016) “Islamic banking: Good for growth?”, Economic Modelling, 59,pp.387-401.

Jawadi F., Jawadi N., Cheffou A.I Ameur H.B., Louhichi W.( 2017) “Modelling the effect of the geographical environment on Islamic banking performance: A panel quantile regression analysis", Economic Modelling, Economic Modelling, http://dx.doi.org/10.1016/j.econmod.2017.01.018

Khattak N. \& Ur-rehman K. (2010), "Customer Satisfaction and Awareness of Islamic Banking System in Pakistan", African Journal of Business Management, 4(5), pp.662-671.

Kamla R.,\& Alsoufi R.(2015) “Critical Muslim Intellectuals' discourse and the issue of'Interest' (riba): Implications for Islamic accounting and banking”, Accounting Forum 39, pp.140-154. 
Kumru Ç.S. \& Sarntisart S.(2016) "Banking for those unwilling to bank: Implications of Islamic banking systems", Economic Modelling, 54, pp.1-12.

Rahman J.U.I.Z. (2017)," Awareness and willingness towards Islamic banking among Muslims: an Indian perspective ", International Journal of Islamic and Middle Eastern Finance and Management, Vol. 10 Iss 1 pp. - Permanent link to this document:http://dx.doi.org/10.1108/IMEFM-01-2016-0017.

Rosman R. , Wahab N.A. \& Zainol Z.(2014) “ Efficiency of Islamic banks during the financial crisis: An analysis of Middle Eastern and Asian countries", Pacific-Basin Finance Journal, 28,pp. 76-90.

Okumus, 2005 "Interest-free banking in Turkey: a study of customer satisfaction and bank selection criteria", Journal of Economic Cooperation. 2005, 26 (4) (2005), pp. 51-86.

Naser K. , Salem A.\& Al, NUSEIBEH R. (2013), "Customers Awareness and Satisfaction of Islamic Banking Products and Services: Evidence from the Kuwait Finance House", International Journal of Marketing Studies, 5(6).

Maswadeh S.N.(2014) "An Evaluation of SMEs Satisfaction toward Jordanian Islamic Banks Service Quality", 2nd Global conference on business, economics, management and tourism, 30-31 October 2014, Prague, Czech Republic.

Mohammad J., Quoquab F., Omar R.(2016) "Factors Affecting Organizational Citizenship Behavior among Malaysian Bank Employees: The Moderating Role of Islamic Work Ethic"; 6 ${ }^{\text {th }}$ International Research Symposium in Service Management, IRSSM-6 2015, 11-15 August 2015, UiTM Sarawak, Kuching, Malaysia; Procedia - Social and Behavioral Sciences 224 , pp. 562- 570.

Saiti B.(2015) "The Awareness and Attitude towards Islamic Banking: A Study in Malaysia", Global Review of Islamic Economics and Business, Vol. 2, No.3, pp.172-196.

Subramaniam M. \& Tanwani K.K. ( 2014) Perspectives of smes on the emergence of islamic banking in the sultanate of oman - the golden hands coming together for sustainable growth; ; International Journal of Humanities and Social Sciences (IJHSS), ISSN(P):2319-393X; ISSN(E): 2319-3948.

Wanke P. , Azad M.D.A.K.A, Barros C.P. (2016) “Predicting efficiency in Malaysian Islamic banks:A two-stage TOPSIS and neural networks approach", Research in International Business and Finance, 36 , p. 485-498.

Wulandari D., \& Subagio A.(2015) "Consumer Decision Making in Conventional Banks and Islamic Bank based on Quality of Service Perception", $2^{\text {nd }}$ Global Conference on Business and Social Science-2015, GCBSS-2015, 17-18 September 2015, Bali, Indonesia.

\section{APPENDICES: ANOVA According to Age}

\begin{tabular}{|l|l|l|l|l|l|l|}
\hline Item & Age Group & N & Mean & SS & F & P \\
\hline
\end{tabular}




\begin{tabular}{|c|c|c|c|c|c|c|}
\hline \multirow{5}{*}{ Friendly and helpful staff } & $20-25$ & 127 & 1.67 & .84 & \multirow{5}{*}{9.275} & \multirow{5}{*}{0.000} \\
\hline & $26-30$ & 108 & 1.85 & 1.01 & & \\
\hline & $31-35$ & 105 & 1.95 & .89 & & \\
\hline & $36-40$ & 110 & 2.39 & 1.08 & & \\
\hline & $41+$ & 50 & 1.88 & .77 & & \\
\hline \multirow{5}{*}{ Regard and respect for people } & $20-25$ & 127 & 2.18 & 1.20 & \multirow{5}{*}{4.876} & \multirow{5}{*}{0.001} \\
\hline & $26-30$ & 108 & 2.38 & 1.32 & & \\
\hline & $31-35$ & 105 & 1.91 & .88 & & \\
\hline & $36-40$ & 110 & 2.46 & 1.23 & & \\
\hline & $41+$ & 50 & 1.86 & .83 & & \\
\hline \multirow{5}{*}{$\begin{array}{l}\text { A more attractive and unusual } \\
\text { banking }\end{array}$} & $20-25$ & 127 & 3.06 & 1.33 & \multirow{5}{*}{4.455} & \multirow{5}{*}{0.002} \\
\hline & $26-30$ & 108 & 3.12 & 1.23 & & \\
\hline & $31-35$ & 105 & 2.77 & 1.08 & & \\
\hline & $36-40$ & 110 & 3.20 & 1.27 & & \\
\hline & $41+$ & 50 & 2.46 & 1.05 & & \\
\hline \multirow{5}{*}{$\begin{array}{l}\text { Customer service quality (Fast. } \\
\text { efficient and error-free service) }\end{array}$} & $20-25$ & 127 & 2.54 & 1.18 & \multirow{5}{*}{3.434} & \multirow{5}{*}{.009} \\
\hline & $26-30$ & 108 & 2.84 & 1.25 & & \\
\hline & $31-35$ & 105 & 2.58 & 1.11 & & \\
\hline & $36-40$ & 110 & 2.75 & 1.16 & & \\
\hline & $41+$ & 50 & 2.16 & 1.09 & & \\
\hline \multirow{5}{*}{ Banking image and popularity } & $20-25$ & 127 & 2.75 & 1.20 & \multirow{5}{*}{4.613} & \multirow{5}{*}{0.001} \\
\hline & $26-30$ & 108 & 3.03 & 1.34 & & \\
\hline & $31-35$ & 105 & 2.82 & 1.28 & & \\
\hline & $36-40$ & 110 & 2.54 & 1.04 & & \\
\hline & $41+$ & 50 & 2.24 & 1.06 & & \\
\hline \multirow{5}{*}{$\begin{array}{l}\text { Some services and facilities not } \\
\text { provided by other banks }\end{array}$} & $20-25$ & 127 & 2.72 & 1.21 & \multirow{5}{*}{2.967} & \multirow{5}{*}{0.019} \\
\hline & $26-30$ & 108 & 2.90 & 1.23 & & \\
\hline & $31-35$ & 105 & 2.66 & 1.15 & & \\
\hline & $36-40$ & 110 & 2.60 & 1.07 & & \\
\hline & $41+$ & 50 & 2.24 & .96 & & \\
\hline \multirow{5}{*}{$\begin{array}{l}\text { Attractive product, process and } \\
\text { service tariffs }\end{array}$} & $20-25$ & 127 & 2.82 & 1.23 & \multirow{5}{*}{5.495} & \multirow{5}{*}{0.000} \\
\hline & $26-30$ & 108 & 3.12 & 1.33 & & \\
\hline & $31-35$ & 105 & 2.77 & 1.03 & & \\
\hline & $36-40$ & 110 & 2.91 & 1.15 & & \\
\hline & $41+$ & 50 & 2.20 & .93 & & \\
\hline \multirow{5}{*}{$\begin{array}{l}\text { The same offers are done by } \\
\text { Islamic bank / participation as } \\
\text { commercial banks }\end{array}$} & $20-25$ & 127 & 2.64 & 1.42 & \multirow{5}{*}{3.391} & \multirow{5}{*}{0.009} \\
\hline & $26-30$ & 108 & 2.88 & 1.45 & & \\
\hline & $31-35$ & 105 & 2.35 & 1.15 & & \\
\hline & $36-40$ & 110 & 2.81 & 1.04 & & \\
\hline & $41+$ & 50 & 2.36 & 1.17 & & \\
\hline & $20-25$ & 127 & 2.69 & 1.54 & & \\
\hline Home and workplace closeness & $26-30$ & 108 & 3.06 & 1.33 & 2.714 & .029 \\
\hline & $31-35$ & 105 & 2.52 & 1.35 & & \\
\hline
\end{tabular}




\begin{tabular}{|c|c|c|c|c|c|c|}
\hline & $36-40$ & 110 & 2.64 & 1.18 & & \\
\hline & $41+$ & 50 & 2.94 & 1.25 & & \\
\hline \multirow{5}{*}{ The Bank follows Islamic rules } & $20-25$ & 127 & 1.53 & 1.01 & \multirow{5}{*}{2.496} & \multirow{5}{*}{0.042} \\
\hline & $26-30$ & 108 & 1.62 & 1.17 & & \\
\hline & $31-35$ & 105 & 1.86 & 1.20 & & \\
\hline & $36-40$ & 110 & 1.47 & .87 & & \\
\hline & $41+$ & 50 & 1.40 & 1.07 & & \\
\hline \multirow{5}{*}{$\begin{array}{l}\text { I trust the management of the } \\
\text { bank }\end{array}$} & $20-25$ & 127 & 2.42 & 1.44 & \multirow{5}{*}{4.458} & \multirow{5}{*}{0.002} \\
\hline & $26-30$ & 108 & 2.38 & 1.32 & & \\
\hline & $31-35$ & 105 & 2.45 & 1.41 & & \\
\hline & $36-40$ & 110 & 1.87 & 1.04 & & \\
\hline & $41+$ & 50 & 1.90 & 1.37 & & \\
\hline \multirow{5}{*}{$\begin{array}{l}\text { My personal data and accounts } \\
\text { are not shared with third } \\
\text { parties }\end{array}$} & $20-25$ & 127 & 2.72 & 1.42 & \multirow{5}{*}{3.670} & \multirow{5}{*}{0.006} \\
\hline & $26-30$ & 108 & 2.66 & 1.47 & & \\
\hline & $31-35$ & 105 & 3.28 & 1.28 & & \\
\hline & $36-40$ & 110 & 2.75 & 1.45 & & \\
\hline & $41+$ & 50 & 2.56 & 1.61 & & \\
\hline \multirow{5}{*}{$\begin{array}{l}\text { Services provided in } \\
\text { participation banking are more } \\
\text { qualified }\end{array}$} & $20-25$ & 127 & 2.51 & 1.31 & \multirow{5}{*}{3.037} & \multirow{5}{*}{0.017} \\
\hline & $26-30$ & 108 & 2.70 & 1.28 & & \\
\hline & $31-35$ & 105 & 2.96 & 1.41 & & \\
\hline & $36-40$ & 110 & 2.93 & 1.33 & & \\
\hline & $41+$ & 50 & 2.38 & 1.50 & & \\
\hline \multirow{5}{*}{$\begin{array}{l}\text { Participation banking } \\
\text { suggestions is highly qualified }\end{array}$} & $20-25$ & 127 & 3.00 & 1.32 & \multirow{5}{*}{2.124} & \multirow{5}{*}{0.077} \\
\hline & $26-30$ & 108 & 2.69 & 1.35 & & \\
\hline & 31-35 & 105 & 3.18 & 1.40 & & \\
\hline & $36-40$ & 110 & 3.04 & 1.39 & & \\
\hline & $41+$ & 50 & 2.74 & 1.66 & & \\
\hline
\end{tabular}

